\title{
Protection of Trade Secrets in Polish and European Legislation
}

\author{
Piotr Widerski ${ }^{1}$ \\ ${ }^{1}$ Department of Law and Social Sciences, Wyższa Szkoła Finansów i Prawa w Bielsku-Białej \\ Tańskiego 5 43-382 Bielsko-Biała - Poland
}

\begin{abstract}
Trade secrets are valuable business assets to all companies on the market irrespective of their size and sector. Empirical evidence prompts clear dependency between innovation and trade secret protection (Ec.europa.eu, 2013). Trade secrets represent the results of $R \& D$ investments, innovation and creativity. They are often located as the decisive element of economic advantage in business relationship. The lack of sufficient legal protection of secrets reduces confidence of business creators, researchers and innovators. A current state of protection in the $\mathbf{E U}$ has proven to be inadequate to create a satisfactory level of entrepreneurship. Directive 2016/943 endorses a minimum standard requirement for the $\mathrm{EU}$ legislation but the Member States may introduce to their own legal systems more far-reaching protection against unlawful acquisition, use or disclosure of trade secrets. Trade secrets play an important role in protecting the exchange of know-how between businesses, especially SMEs, and research institutions both within and across the borders of the internal market, in the context of research, development, and innovation. Trade secrets are one of the most commonly used forms of protection of intellectual creation and innovative knowhow by businesses, yet at the same time, they are not sufficiently protected by the existing European Union legal framework.
\end{abstract}

Index Terms - trade secrets, undisclosed know-how, intellectual property rights, confidential business information, intangible assets.

\section{INTRODUCTION}

The Directive of the European Parliament and the Council of the European Union 2016/943 of 8 June 2016 on the protection of secret know-how and non-public commercial information (business secrets) against their unlawful acquisition, use and disclosure, entered into force on 5 July 2016. This document deals with the basic right of enterprises, which is the right to secrecy. The Polish Constitution of 1997, in article 49, ensures freedom and protection of communication secrets. Protection of secrecy is a personal right of every human being and can be limited only in cases and manner specified in the Act. In turn, the Polish Civil Code has referred to the concept of secrecy

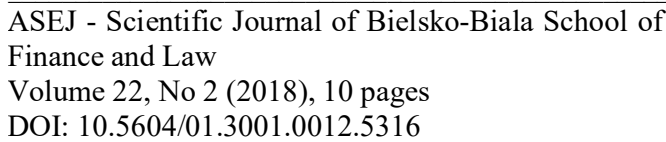

Received 03 April 2018; Accepted 15 July 2018 twice. First of all, in article 23 of the Civil Code, where the protection of correspondence is provided for, and then in article $55^{1}$ of the Civil Code, where business secret is mentioned among the components of the enterprise. Secrecy of correspondence and company secret are assets under special protection. They are characterized by inalienability; they are absolute and effective laws erga omnes.

The dominant view in legal literature (Gnela, 2015) is that civil law protection of personal rights should be based on the construction of subjective rights (Pazdan, 2007), although there also other views (Gawlik, 1985). The catalogue of personal goods listed in article 23 of the Civil Code is not a numerus clausus. The legislator, by using the phrase 'in particular', indicates that only some of the most important goods are listed in the catalogue. Also scientific, inventive and rational creativity may be an constituent of a company's secret.

It should be noted that personal goods belong not only to natural persons, but also to legal persons. This is proven in article 43 of the Polish Civil Code, which stipulates that the provisions on the protection of personal rights shall apply accordingly to legal persons. Therefore, all kinds of claims that arise as a result of a violation of personal rights of a legal person can be claimed in accordance with article 24 of the Civil Code. This is beneficial to the disadvantaged parties. The judgment of the Supreme Court of 11 October 2005 stated that: from article 24 of the Civil Code the presumption of illegality of action results, which in a beneficial way, for the disadvantaged party, affects the distribution of the burden of proof. This presumption should, therefore, be rebutted by the defendant (article 6 of the Civil Code); it is the defendant who in the process of protection of personal rights is required to demonstrate the existence of circumstances justifying this action, and thus excluding unlawfulness. However, it should be noted that the case laws concerning interpretation of article 24 of the Civil Code are not uniform. The Court of Appeal in Warsaw in the judgment of 20 October 2014 pointed out that although article 43 of the Civil Code imposes the application of provisions on personal goods also to legal persons, these provisions should not be used

Regular research paper: Published 20 July 2018

Corresponding author's e-mail:pwiderski@gmail.com

Copyright (C) 2018 This is an open access article distributed under the Creative Commons Attribution CC-BY-NC 4.0 License. 
explicitly, but appropriately, taking into account the nature of a particular personal good, as well as differences between organizational units and natural persons (...) due to the specifics of a personal good, which is the image, it is only legitimate for individuals to be protected and not for legal persons. Consecutively, in a judgment of 24 June 2014 the Łódź Court of Appeal assumed that (...) provisions on the protection of personal rights of natural persons apply only to legal persons, respectively. The appropriate application of article 23 of the Civil Code excludes from the scope of this protection such personal human rights, which in the case of a legal person cannot be taken into account at all, such as life, health, dignity or image. The District Court in Wrocław in the judgment of 13 May 2014 pointed out that a legal person cannot have an image which is neither a photograph of the building in which it has its registered office, nor a company logo or other symbol. In addition, the Łódź Court of Appeal in the judgement of 7 November 2013 assessed that the image of people who are part of the legal person's institutions, or even the image of the whole team is not an image of a legal person. However, the Appeal Court in Katowice in the judgment of 13 February 2014 acknowledged that by the concept of 'image' of a legal entity should be understood the general characteristics of this entity in general view, which particularly affect the opinion of this legal entity and its commercial reputation (...) The violation of good reputation of a legal person can occur primarily by accusing that person, in particular the authorities of improper conduct that could expose the legal person to the loss of confidence needed to do business (...). Similarly, the Bialystok Appeal Court in the judgment of 27 February 2014 recognized that due to the fact that economic activity is performed by a significant part of legal persons, their good name understood as a reputation or image becomes particularly important. The Supreme Court in its judgment of 7 October 2009 stated that using in the judgment under appeal the concept of 'image' in relation to the claimant, in the context of such terms as 'good name', 'company', 'reputation' and defining by means of these concepts one of the personal good of the plaintiff, which was violated by the defendant, means that the good is the established reputation of the plaintiff and his reputation as an entrepreneur. An open catalogue of personal rights contained in article 23 of the Civil Code and relevant, pursuant to article 43 of the Civil Code, defines that the application of this provision to the personal rights of legal persons 'image' should be understood as a concept that includes the perception of all the generally felt features characterizing the entity that this term refers to (Partyk, 2015).

In addition to the issue of protection of personal rights provided for in the Civil Code, the national legislator provided for the protection of these goods also in other acts such as the Copyright and Related Rights Act of 4th February 1994, or the Industrial Property Act. In turn, the provisions on the protection of business secrets, apart from those contained in the Civil Code, are also included in the Act of 16 April 1993 on Combating Unfair Competition. Here, however, the question should be asked whether the protection of personal good of a legal person, including business secret, is regulated in a sufficient, comprehensive and complete manner. Another question that naturally arises is: whether and to what extent, the currently applicable national provisions on the protection of trade secrets are convergent with the new EU directive 2016/943. According to the Directive 2016/943, its provisions should have been be transposed into the order of national legislation by 9 June 2018 .

\section{II.COMPANY SECRET - ANALYSIS OF CURRENTLY APPLICABLE PROVISIONS IN POLISH LEGAL SYSTEM}

The concept of an enterprise in the Polish legal order is regulated in article 55 of the Civil Code $^{1}$ which stipulates that an enterprise is an organized set of intangible and tangible assets intended for running a business. In business trading, the enterprise functions as an organized integrity separated in terms of organization, appearing as intrinsic and intangible property (Gniewek, 2010). Entrepreneurs, however, are entitled to this whole (integrity), which can be defined as an absolute subjective right. It is worth noting that the concept of an enterprise in the meaning of article $55^{1}$ of the Civil Code is of objective nature and characteristic of a state-owned enterprise, which operated under Article 38.3 of the Act of 21 September 1981 on state-owned enterprises (Miemiec, 2013). As the Supreme Court states: the statutory definition of an enterprise in the subjective sense detaches this concept from the entity to which the enterprise belongs and emphasizes the material and non-material components that make up the enterprise, as well as their organizational and functional combination [Judgement of 8 April 2003]. In turn, this definition of an entity i.e. an entrepreneur to which the enterprise belongs, is found in the Act of 6 March 2018 on Business Law. Pursuant to Article 4 of the Act, in the section on the rights of entrepreneurs, the entrepreneur is a legal person or an organizational unit that is not a legal person who performs an economic activity and who is granted legal capacity by separate law. Entrepreneurs are also partners of a civil partnership in the scope of their business activity.

The importance of an enterprise in the European law differs significantly from the meaning of article $55^{1}$ of the Polish Civil Code (Kurcz, 2012). Pursuant to this article an enterprise is a group of various intangible and material components needed to perform business activities. Among intangible assets, the legislator also mentions the secrets of an enterprise.

According to A. Michalak, the source of protection of business secrets in Polish law can be divided into the following groups:

a. direct and indirect sensu stricto sources of protection, e.g. article 11 of the Act on Combating Unfair Competition, article 1012 of the Labour Code, article 79 on Industrial Property Law, article 72 1, articles 415 et seq., articles 405 et seq., articles. 23-24 CC;

b. sources containing regulations regarding the protection of trade secrets, which, without defining the very concept of business secret, grant the authorized entity fragmentary rights related to the protection of this secrecy, e.g. article 428 of the Code of Commercial Companies; 
c. sources containing declarative norms ordering protection of business secrecy without granting certain claims to the right holder, e.g. article 64 paragraph 3 of the Industrial Property Law;

d. sources dedicated to the protection of separate secrets, which in some cases constitute company secrecy, e.g. article 109 of the Banking Act;

e. procedural sources of information protection, e.g. article 479 of the Civil Code or article 62 of the Office of Competition and Consumer Protection (Michalak, 2006).

Among the sources mentioned above, the most important provisions for the protection of trade secrets are sensu stricto direct and indirect provisions, and in particular article 11 paragraph 4 of the Act on Combating Unfair Competition, where the so called legal definition of a company secret is given. This provision defines trade secret as 'publicly disclosed technical, technological, organizational information, or other information of an economic value, for which the entrepreneur has taken the necessary actions to preserve its confidentiality'. In addition, the Act on Combating Unfair Competition in article 3 , paragraph 1 defines the notion of an act of unfair competition and, among these acts, the breach of business secrecy is mentioned.

Having analyzed the provisions of the Act on Combating Unfair Competition, it should be noted that the assumptions of this law are modelled, to a certain extent, on the provisions of the Act of 1926 on Combating Unfair Competition, but as far as the fundamental issue is concerned, there is a shift in the burden of responsibility from criminal law to civil law. As in the Act of 1926, the legislator in the content of the Act on Combating Unfair Competition decided to inconclude the so called small and large general clauses. The phrase used in article 1 paragraph 1 of the 1926 Act, referred to as 'crashing into the clientele of the entrepreneur', corresponds currently to the term contained in article 3 paragraph 1 of the Act on Combating Unfair Competition i.e. an activity that 'threatens or violates the interests of another entrepreneur or client'. In turn, the so called 'large general clause' from article 3 of the Act of 1926, corresponds to article 3 of the Act on Combating Unfair Competition. It can be said that the content of the so called large general clause remains unchanged, and in the same way as in the Act of 1926, an action of unfair competition is defined as an action contrary to the law or good manners.

Another piece of legislation that directly regulates the protection of business secrets is the Labour Code on 26 June 1974. Pursuant to article $100 \$ 2$ point 4 of the Labour Code, the employee while being employed, is obliged to keep confidential information, the disclosure of which might expose the employer to a detriment. Whereas the provisions of article $101^{2} \S 1$ of the Labour Code on the prohibition of competition, provide that the employer may enter into a non-competition agreement with an employee after the termination of the employment relationship with an appropriate remuneration. This does not mean that the employee, after termination of employment, can freely disclose all company secrets. This prohibition should be interpreted, primarily as a ban on the use of information that the employee obtained during the employment relationship in a way that could create competition for the former employer. This concerns all information, all the knowledge acquired by the employee while performing his or her official duties, which is referred to as the so called professional experience.

The issue of interpretation of the provision of article 11 paragraph 2 of the Act on Combating Unfair Competition is under discussion. Is it to be understood as an unlimited entitlement of a former employee who after 3 years can freely dispose of the company's business secrets? The literal wording of this provision is as follows: the provision of section 1 also applies to a person who provided work on the basis of an employment relationship or other legal relationship - by period of three years from its cessation, unless the contract provides otherwise or a state of secrecy has ceased. Authors such as S. Sołtysiński and S. Gogulski believe that the obligation of secrecy of a former employee expires after 3 years (Soltysiński, and Gogulski, 2016). The consequence of such an approach is the adoption of the position that after three years the former employee may transfer, disclose or use someone else's secret information, or acquire such information from an unauthorized person. Consistently, following this line of reasoning, one may come to the conclusion that the provision of article 11 section 1 does not apply to a former employee of the enterprise after 3 years from termination of employment.

A completely different view on this issue is presented by B. Giesen. According to a teleological interpretation, she considers that the provision of article 11 paragraphs 1 and 2 does not give the former employee the right to disclose business secrets after 3 years from the end of a binding contract with the employer. She further states that the company secret is protected until the state of secrecy ceases for various reasons. B. Giesen thinks that article 11 paragraph 2 applies only to the so called 'threshold information' that is between confidential information and information constituting the employee's professional experience (Giesen, 2013).

In the analysis of the above mentioned attitudes, it should undoubtedly be concluded that the current wording of the provision of article 11 paragraph 2 is not understandable because on its basis, it cannot be concluded that this provision entitles a former employee to dispose of a company secret freely after 3 years from the end of employment. Also the second position, presented by B. Giesen, is not entirely convincing as it is not easy to determine which information is the so-called 'threshold information'. Therefore the problem related to the proper interpretation of article 11 paragraph 2 cannot be solved because, as indicated earlier, this provision does not give grounds for the former employee to disclose secrets after 3 years. The author of the paper believes that the teleological interpretation should be used to understand this provision, based on the assumption that paragraph 2 of article 11 refers to the limited scope of activities listed in paragraph 1 of article 11.

In the author's point of view, the only act of unfair competition, which is exempt from liability after the period of three years, is the use of other people's information constituting the secret of the company, but with a certain reservation. This use should be treated i.e. as personal use in a competitive relationship to the former employer. This would mean all the 
confidential information that the former employee would be able to use while conducting business activities that cannot be transferred or disclosed to other entities on the market. To sum up, it can be said that the only situation that will not constitute a violation of the provision of article 11 of the Act on Combating Unfair Competition, is the use of information being a trade secret, provided that this use occurs after 3 years from the termination of the employment relationship. Of course, such use of a company secret may not consist in disclosure or in any transfer of secrets to other entrepreneurs within the meaning of article 2 of the Act on Combating Unfair Competition.

\section{III.COMPANY SECRET IN THE EUROPEAN REGULATIONS AND IN DIRECTIVE 2016/943}

In the beginning it is important to answer the question of the definition of an enterprise in the sense of EU law. In fact, it can be said that there is no such general definition literally given in statutory provisions. Article 49 of the Treaty on the Functioning of the European Union (TFEU) does not define the concept of an enterprise. It only defines the concept of entrepreneurship as taking up and pursuing activities as a self-employed person, as well as establishing and managing enterprises. At the same time, in order to determine the operating conditions of a company, this provision refers to the laws of individual countries [Treaty on the Functioning of the European Union, Journal of Laws of EU 2016 C 202, p.1]. The general concept of defining the notion of an enterprise has been taken by the Court of Justice of the European Union (CJEU) in its case law. It acknowledged by way of an extensive interpretation, based on article 101 and 102 TFEU, that an enterprise is any entity involved in an economic activity, regardless of its legal status and the method of financing (Gancarz, 2011). This position was also found in point 4 of the justification to the Commission Regulation (EU) on the application of article 107 and 108 of the Treaty on the Functioning of the European Union to de minimis assistance. However, it should be emphasized that such a definition of an enterprise was functionally created for the needs of EU competition law and differs from the definition used in article $55^{1}$ of the Civil Code.

It is believed that the first act that introduced the concept of business secrets into the European legal order was the Agreement on Trade Related Aspects of Intellectual Property Rights (TRIPS). This agreement referred to the Paris Convention on Industrial Property Protection of 20 March 1883 and article 10 bis of the Convention [States that are members of the Union are obliged to provide natural and legal persons of States that are members of the Union with effective protection against unfair competition. Paragraph 2 - an act of unfair competition is any act of competition that is contrary to honest customs in the field of industry or trade] which requires the Member States to protect against 'acts of competition contrary to honest customs in industry or trade'(Michalak, 2006). However, the Paris Convention alone did not regulate the concept of 'business secrets'. Only the TRIPS agreement in article 39 section 1 lists 'undisclosed information' as a good that should be protected. Subsequently, paragraph 2 article 39 includes the conditions which should be met in order to protect the information. These requirements are met if the information is: a) confidential in the sense that, as a whole or in a specific set and assembly of its elements, it is not generally known or easily accessible to people in circles who normally deal with this type of information; b) has a commercial value because it is confidential; and (c) has been subjected to reasonable, under certain circumstances, actions aimed at preserving the confidentiality of the information by a person who is legally in a proper control of the information. These conditions, in principle, have remained unchanged up to the present time because on the basis of this provision the notion of company secret has been defined in Article 11 (4) of the Act on Combating Unfair Competition.

A definition of a similar meaning is also given in the Directive of the European Parliament and of the Council (EU) on the protection of secret know-how and non-public commercial information (trade secrets) against their unlawful acquisition, use and disclosure (Directive 2016/943). Article 2 of the Directive contains a definition of business secrets that coincides with the definition of article 39 paragraph 2 of the TRIPS Agreement. To sum up, according to the established standard, if the information is to be considered a trade secret, it should meet all three requirements: i.e.: confidentiality, commercial value and protection of information.

Directive 2016/943 was adopted after many years of in-depth discussion on the effectiveness of protection of business secrets in the European Union. The analysis has shown the absence of appropriate harmonization of the existing regulations in this area. The lack of uniform regulations of basic definitions, which has a negative impact on the protection of enterprises' interests in international transactions, has been indicated. According to the Working Document of the European Commission, out of 28 EU countries, as many as 18 do not have legal provisions defining the concept of business secrets [Working Document of the European Commission- Summary of the Results Estimation, SWD 2013, 472 final, Brussels, 8 November 2013]. In 20 countries, there are no regulations on the possibility of calculating the amount of compensation based on license fees, and in 16 countries the provisions in the field of criminal law are not protective enough. Only three countries of the entire Union seem to have implemented adequate procedures for the enforcement of civil proceedings in the area of protection of business secrets. Taking into account the above mentioned facts, it should be stated that the adoption of uniform rules will allow for more effective protection of economic interests. In most European countries appropriate provisions ensuring confidentiality of trade secrets during civil law proceedings do not exist. This fact directly threatens the disclosure of protected information. The currently existing fragmentary protection of trade secrets does not foster the economic turnover.

As outlined in the Preamble 36 of Directive 2016/943, the purpose of the passed laws is 'to ensure a smooth functioning of the internal market by establishing a sufficient and comparable level of redress within the internal market in the event of unlawful acquisition, use or disclosure of business secrets'. At the same time, however, point 27 of the Preamble 
states that 'the purpose of the Directive is not to establish harmonized rules for judicial cooperation, jurisdiction, recognition and enforcement of judgments in civil and commercial matters or to regulate the question of applicable law'. In accordance with the position of the European Commission, after the analysis of relevant provisions regarding the protection of trade secrets in individual EU countries, it was decided to choose the appropriate protection option. The EC departments analysed five different options in terms of their effectiveness, efficiency and costs. The option which involved the convergence of remedies provided for in the national civil law provisions applied in the case of misappropriation of trade secrets, turned out to be the most effective [Working Document of the European Commission- Summary of the Results Estimation]. At the same time, the remaining four variants were rejected, including the one that assumed harmonization not only of civil law but also of criminal law in individual EU countries. It was considered that the harmonization of criminal law provisions would go beyond the existing protection of intellectual property rights provided for in criminal law, which currently is not harmonized at the EU level. It was therefore concluded that the optimal way to ensure a uniform approach to the protection of trade secrets in the EU is passing a directive establishing a certain minimum standard for protection measures. These measures should be of civil law nature and should be subject to transposition process into the national regulations of all EU countries. At the same time, Article 1 of Directive 2016/943 provides that, in accordance with the provisions of the Treaty on the Functioning of the European Union, the Member States may adopt more far-reaching protection against the unlawful acquisition, use or disclosure of business secrets than the protection required by this Directive.

The Preamble to Directive 2016/943 also settles a doctrinal dispute over whether the right to protection of business secrets is exclusive. As it was stated in point 16 of the Preamble in the interests of innovation and in order to promote competitiveness, the provisions of this Directive should not grant any exclusive rights to know-how or protected information as business secret. This point also confirms the legality of obtaining the content of certain information through an independent discovery and allows the possibility of product/process reproduction through the so called reverse engineering, which is directly reflected in article 3 of Directive 2016/943. However, some authors argue that despite the existence of item 16 of the Preamble, the proposal to qualify company secret for an entry in the catalogue of rights of subjective and absolute nature, should be supported (Zdyb, Sieradzka and Michalak, 2016).

Directive 2016/943 requires the Member States to set up adequate measures to ensure that EU-wide investigations are available throughout the EU and that civil damages are remedied in order to harmonize legislation effectively. For this purpose, in articles 6 and 7 of the Directive the nature of general measures, procedures and legal remedies which are to be applied in pursuing claims, have been specified. The articles describe measures that may be applied by a court at the stage of litigation and also specify measures which the court may decide as a result of an enforceable statement of unlawfulness of the perpetrator's actions. Among the measures that can be applied by the court at the stage of the dispute, articles 10 and 11 of the Directive mention temporary and safeguard measures as well as conditions of application of these measures in relation to the alleged infringer. The minimum measures that Member States must apply to potential perpetrators are: temporary cessation, ban on using or disclosing business secrets; a prohibition on the production, offering, placing on the market or using infringing goods, or the import, export or storage of goods constituting an infringement for these purposes; seizure or transfer of goods that are suspected to constitute an infringement. These measures are largely aimed at preventing the alleged perpetrator from introducing the goods on the market. The provisions of the directive also provide for the possibility of establishing by the court appropriate protection which, if paid by the applicant, could lead the court to take certain provisional or protective measures against the potential perpetrator. In the same way, the respondent may apply for collateralization in the event of losses sustained by the plaintiff when the alleged offender intends to continue his/her activity which is the subject of the dispute and is convinced of his/her innocence. The court may also order the applicant to compensate the defendant or injured third parties for any damage suffered as a result of the measures set out in article 10 of the Directive.

When the court concludes unlawful acquisition, use or disclosure of a trade secret, the Member States must, at the request of an applicant, apply one or more court orders or remedies, for instance: cessation or, depending on the case, prohibition of using or disclosing the secret of the enterprise; a ban on the production, offering, placing on the market or using infringing goods or the prohibition on importing, exporting or storing infringing goods for these purposes; the destruction, in whole or in part, of all documents, objects, materials, substances or electronic files which include or use trade secret or, where appropriate, delivering them to the applicant. In addition to the aforementioned orders, the court may order corrective measures, such as withdrawal of infringing goods from the market, depriving the infringing goods of the infringement features, destroying the infringing goods or, if applicable, withdrawing them from the market.

Directive 2016/943 in addition to the purpose of harmonizing European regulations, is supposed to systematise and define concepts that function in the semantic area of the term protection of business secrets. Article 4 of the Directive indicates the circumstances in which unlawful acquisition, use and disclosure of secrets occur. The meanings of these concepts are explained and developed here. It has been found that the unlawfulness of the perpetrator's action is determined by the court's objective recognition that the behaviour is contrary to what is commonly known as honest commercial practices. Furthermore, in order to specify the conditions for determining the occurrence of use or disclosure, the legislator referred to three indications. Therefore, one can talk of the use or disclosure of a trade secret when a person acquires the trade secret unlawfully; violates a confidentiality agreement or other obligation not to disclose business secrets, and also if a person violates a contractual or other obligation to limit the use of 
business secrets. Article 4 of the Directive also states that only intentional acts bear the hallmarks of an unlawful act of obtaining, using and disclosing a business secret. In the event of an unintentional action, the provisions of article 13 may apply, stating that in such a case the judicial authority may order the payment of monetary compensation to the victim instead of applying the measures provided for in article 12. In such a case, the compensation awarded should not be higher than the sum of the license fees or fees that would be payable if that person applied for permission to use the trade secret in question for a period in which the use of the trade secret would be prohibited. It is also worth noting that pursuant to article 14 paragraph 2, when determining the amount of compensation, the court should take into account not only damnum emergens losses suffered by the disadvantaged person, but also lost profits of lucrum cessans as negative economic consequences for the disadvantaged party.

Another important fragment of Directive 2016/943 regulates the confidentiality of business secrets during court proceedings. Article 9 of the Directive is a safeguard for the ongoing proceedings against the risk of disclosure of information that may destroy the company's secret. The obvious objective of the parties involved in the court proceedings is to protect all information that may constitute a company secret. Among the companies participating in the survey conducted by the European Commission, as much as $78 \%$ of entities believe that protection of secrets in court cases is insufficient, and thus entrepreneurs are afraid to take legal action [Commission Staff Working Document, SWD (2013) 471 final, p. 88, Brussels, 28 November 2013]. Therefore, article 9 of the Directive requires the Member States to ensure confidentiality of business secrets during court proceedings by applying appropriate measures. The minimum information protection measures mentioned in the Directive are: limiting access to all documents containing company secrets or alleged company secrets, limiting access to hearings and meetings during which company secrets may be disclosed, and the possibility of making judgments available to persons outside the process, with reworded or removed confidential information. The deadline for the implementation of relevant provisions in individual EU countries was 9 June 2018 .

\section{IV.PROPOSAL FOR DE LEGE FERENDA LEGISLATION TO TRANSPOSE} THE PROVISIONS OF DIRECTIVE 2016/943

In March 2010 the European Commission adopted "Europe 2020" strategy for smart, sustainable and inclusive growth. This document was the Commission's response to the economic crisis and an attempt to establish appropriate development priorities, set targets and propose actions to ensure sustainable economic growth. There were seven flagship projects, including, among others, a thematic priority called 'the Union of Innovations'. It is a project to improve every element of the innovation process, from initial research to the commercial use of the end results. In this context, the Commission considered that the implementation of the EU economic priorities should be based on uniform legal provisions. It was considered that the existing differences in the protection of intellectual property in individual EU countries are very significant because they hinder free flow of goods and services between countries. Trade secrets are essential for research, the implementation of which requires the exchange of valuable information between partners in individual Member States. Trade secrets were also found not to be sufficiently protected in the EU and therefore exposed to misappropriation. Among the main disadvantages of the current system, the lack of a common and stable legal framework for the protection of trade secrets was discovered [Commission Staff Working Document - summary of the results assessment, SWD 2013, 472 final, p.2, Brussels, 28 November 2013].

As presented above, Directive 2016/943 is aimed at providing a certain standard for the protection of confidential information by applying minimum protection measures, uniform throughout the European Union. It should be stated that the current shape of Polish regulations does not meet this minimum standard. Therefore, it is necessary to adapt the provisions of national law to the guidelines of the new Directive.

The main problem the European Commission paid attention to while working on the Directive, was the lack of a uniform definition of the concept of a business secret in all EU countries. In the Polish legal system, the definition of a business secret is regulated in article 11 paragraph 4 of the Act on Combating Unfair Competition. When analyzing the wording of this provision, as well as the wording of article 2 of Directive 2016/943, it can be concluded that the definitions are similar, although there are some significant differences. First of all, in the Polish law, business secrets are understood as all information, both in terms of content and form of communication, as long as it is confidential and has an economic value. The EU legislator, in turn, recognized that the company secret is any confidential information of a commercial value, but in order for such information to be protected it should appear as a whole or in a specific set and collection of elements. This means that the form of information that can be the subject of protection differs on the basis of the discussed provisions. So, in accordance with article 11 paragraph 4 of the Act on Combating Unfair Competition, a single information item regarding the direction of the enterprise's development could be considered as the company's secret. However, within the meaning of the new Directive, such information could be the subject of protection only when this single information item is included in, for example, a company's development strategy. The consequence is, that the protection is not subject to individual information but to a certain amount of information or presented in a particular set and collection of elements. The second difference in the content of the discussed provisions is another way of defining the state of confidentiality. According to the Act on Combating Unfair Competition, the state of confidentiality ceases to exist when the information is made public, whereas the Directive in article 2 paragraph 1 point (a) specifies that the state of confidentiality ceases when the information becomes generally known or easily accessible to 
persons in circles normally dealing with this type of information. The comparison of these provisions shows that the EU Directive regulates the disclosure of business secrets more precisely. The third difference worth mentioning here is a different way of keeping the information confidential. The Polish regulations state that information is classified if the entrepreneur has taken necessary steps to keep it confidential. However, Directive 2016/943 determines the existence of a state of confidentiality from actions that are reasonable under the circumstances, taken by a person who controls the secret of the enterprise. Without going into semantic considerations of the definitions of the words 'reasonable' and 'necessary', it can be said that the meanings are different and may become the subject of numerous interpretational problems. Not every action will be necessary for a reasonable operation in given circumstances. Similarly, some reasonable actions might prove to be unnecessary. Undoubtedly, in order to protect the confidentiality of information, the entrepreneur should apply both physical and legal protection measures. It is also believed that physical security is a priority in the protection of information inside the company (Zdyb, Sieradzka and Michalak, 2016). This is confirmed by the published rulings of the Supreme Court [Judgement of the Supreme Court of 5 September 2001, I CKN 1159/00, OSNC 2002, No. 5, item 67 and Judgment of 3 October 2000, I CKN 304/00, OSNC 2001, No. 4, item. 59]. The fourth visible difference in the definitions of provisions under discussion, is determination of the nature of information constituting the trade secret. Regulations of the Act on Combating Unfair Competition require this information to be of economic value, whereas the Directive describes this information as having a commercial value. In this case, it can be concluded that the semantic differences are irrelevant and the commercial and economic terms should be used interchangeably. Taking into account all the described differences in the definition of business secrets, it should be noted that in order to harmonize the rules, the Polish legislator should fully adopt the definition written in Directive 2016/943. It can be said that this is a sine qua non condition for the correct transposition of EU regulations into the national order.

The adoption of a single definition of a company secret across the EU will allow for a uniform understanding of protection and equal treatment of litigation participants in the proceedings. At present, it is not easy for courts to refer to identical minimum standards for secrecy protection, because in many countries the definition of a business secret does not exist; for example in Austria, Belgium, Spain, Finland, France or Germany. This does not mean that in these countries the secret of enterprises is not protected. In many countries, there are laws that prohibit the disclosure of business secrets, civil or criminal, regardless of whether a given system has a statutory regulation of a trade secret. The adoption of one definition in all EU countries, as well as the use of similar minimum protection measures, will have particular procedural significance in relation to international transactions throughout the European Union. Therefore, it would be a desirable activity to amend article 11 paragraph 4 of the Act of 16 April 161993 on Combating Unfair Competition.
Another issue that should be taken into consideration when indicating differences between the content of the Act on Combating Unfair Competition and Directive 2016/943, is the way in which the act of breaching the trade secret is described. A much more detailed description can be found in the Directive. The national law only lists types of acts such as the transfer, disclosure, use or acquisition of someone else's information, whereas the Directive describes in detail the nature of these acts, indicating when various types of violations are considered unlawful. In addition, the Directive in article 4, paragraph 4 indicates two possible violations of business secrets, i.e. direct or indirect. In the same paragraph the state of awareness of the perpetrator is emphasized and, consequently, his/her guilt at the time of committing the infringement, acquiring, the use or disclosure of trade secrets is also considered unlawful always whenever, at the time of acquisition, use or disclosure, a person knows or should under given circumstances know that the business secret has been obtained directly or indirectly from another person who was using or disclosing a business secret illegally in the sense of paragraph 3 .

The solutions described above clearly indicate the need to amend the Act on Combating Unfair Competition in the direction of clarifying basic types of violations, as well as determining the state of awareness and fault of the perpetrator. The Polish Act also lacks a detailed list of activities which constitute a breach of secrecy, as specified in article 5 of the Directive, i.e. production, offering or placing of infringing goods on the market and importing, exporting or storing infringing goods for such purposes, it is also considered unlawful to use a trade secret if the person who carried out those acts knew or should have been aware of the unlawful use of a trade secret within the meaning of paragraph 3 .

Attention should also be paid to terminological differences regarding the type of violations in both regulations. National regulation of the Act on Combating Unfair Competition lists the transfer, disclosure, use or acquisition of information among the potential violations of the company's secret. In turn, the Directive indicates the acquisition, use and disclosure of business secrets. It seems that the term 'acquisition' includes both the transmission and acquisition of confidential information, because 'acquisition' is defined by the Directive, among others, as the so called 'unauthorized access', which undoubtedly may arise as a result of the transfer or acquisition of such information. In order to complete the possible unlawful forms of acquiring, it is stated in article 4 paragraph 2 point $b$ of the Directive that the infringement arises from any other proceedings that are considered to be in conflict with fair commercial practices under given circumstances. The EU legislator did not decide in this provision to specify the type of numerus clausus of all possible types of acquisition. It is known, however, that unlawful acquisition is in particular: theft, fraud, bribery, deception or incitement to violate the company's secret. The above differences undoubtedly lead to the unification of the provisions of the Act on Combating Unfair Competition with the provisions of the Directive. 


\section{V.CLAIMS}

The Directive also introduces new regulations regarding the catalogue of claims that are available in the event of a breach of confidentiality. When analyzing article18 of the Act on Combating Unfair Competition (Wojcieszko-Głuszko, 2005) and the regulation of the Directive, it is possible to point to new provisions that Poland as a Member State has to transpose. These are issues such as: the possibility of transferring business secrets to charitable organizations (article 12 paragraph 3 ) and the opportunity to award compensation as a lump sum payment based on at least such elements as the amount of licence fees or royalty that would be due if the perpetrator of the violation applied for permission to use the trade secret in question (article 14 paragraph 2).

Similarly to Polish legislation, the Directive allows not only the possibility of damnum emergens, but also the lost lucrum cessans profits. According to article 14 paragraph 2 of the Directive, one can also claim damages for elements other than economic factors, such as e.g. non-proprietary damage suffered by the holder of business secrets as a result of unlawful acquisition, use or disclosure of business secrets. It seems that the equivalents of this provision in Polish legislation are articles 445 and 448 of the Civil Code, on the basis of which one can demand adequate compensation from the offender for the harm suffered. The Supreme Court in its judgment of 9 February 2000 stated that: the harm compensated by money, regulated in article 445 of the Civil Code, is non-pecuniary damage (...). It should be noted, however, that we are dealing here with the construction of liability based on both illegality and fault; the judgment of the Supreme Court of 12 December 2002 argued that: the condition of liability provided for in art. 448 of the Civil Code is not only the unlawful but also the wrongful act of the perpetrator of the violation of the personal good, and the judgment of the Supreme Court of 19 January 2007 stipulated that: Article 448 of the Polish Civil Code applies only in the case of a culpable violation of personal rights. If the legislator wanted to make the unlawfulness of violating a personal good an only condition of the claims provided for in art. 448 of the Civil Code, he would place this provision in the general part of civil law (within article 24 of the Civil Code). Whereas in art. 24 of the Civil Code there is a reference to the 'rules provided for in the Code' (Romatowska, n.d.).

\section{VI.STATUTE OF LIMITATIONS}

The Directive in article 8 (2) also includes a recommendation to the EU Member States that the length of the limitation period of claims should not exceed 6 years. The basic limitation period written in article $442^{1} \S 1$ is 3 years from the date when the victim learned about the damage and about the person obliged to repair it. The Act on Combating Unfair Competition also provides for the same period in article 20 for acts of unfair competition, ordering proper application of the provisions of the Civil Code. However, it cannot be overlooked that article $442^{1} . \S 1$ of the Civil Code states that this period may not exceed ten years from the date on which the harmful event occurred. In addition, article $442^{1}$. $\S 2$ of the Civil Code provides for a 20 year limitation period if the damage resulted from a crime or misdemeanour. Taking into account the aforementioned provisions, it should be noted that the 6 year limitation period specified in the Directive shortens the possibility of redress starting from the day when the damage occurred. This issue should also be adapted by the Polish legislator.

\section{CIRCUMSTANCES EXCLUDING THE UNLAWFULNESS OF A TRADE SECRET INFRINGEMENT}

The Act on Combating Unfair Competition enumerates cases when a person does not commit a prohibited act, characterized by a threat or a violation of the entrepreneur's interest. The law is not broken by somebody who:

- purchased information constituting the trade secret from the unauthorized entity in good faith, on the basis of a paid legal transaction, - article 11 paragraph 3 of the Act on Combating Unfair Competition;

- being a trade unionist, acts in accordance with the provisions on collective dispute resolution article 12 paragraph 3 of the Code of Association;

- copies the functional features of the product, in particular the construction, design and form that ensures its usability article 13 paragraph 2 .

In contrast, Directive 2016/943 in article 5 permits certain circumstances, as a result of which unlawfulness will not occur (as an exception):

- exercising the right to freedom of speech and information specified in the Charter of Fundamental Rights, including respect for freedom and media pluralism;

- disclosure of incorrectness, failure to act or action in breach of law, provided that the defendant acted in order to protect the general public interest;

- disclosure made by employees to their representatives as part of the authorized exercise of their functions by such representatives in accordance with the European Union or national law, provided that such disclosure was necessary for the performance of those functions;

- protection of a legitimate interest recognized in the European or national law.

Moreover, in article 3 the Directive specifies the situations in which the use and disclosure of company's secrets is lawful. These are:

- independent discovery or creation;

- observation, examination, division into parts or testing of a product or an object that has been made public or which is legally in the possession of the person who obtained the information in question and who does not have a legal obligation to limit the acquisition of a given trade secret;

- exercise of the right to information and consultation of employees or employees' representatives in accordance with the European Union law and national law or the European Union or national practices; 
- $\quad$ any other practices that are considered to be compliant with honest commercial practices under given circumstances.

Analyzing the provisions cited above, it can be noted that Directive 2016/943 extends the catalogue of behaviours excluding the unlawfulness of acts violating the secret of the enterprise (Zdyb, Sieradzka and Michalak, 2016). The new institution mentioned in article $5 \mathrm{~b}$ deserves a particular attention, as it gives the possibility of revealing business secrets in order to protect the interests of general public. In legal literature, this institution is referred to as 'whistleblower protection'. Before the Directive entered into force, disclosure of a trade secret to inform, for example, about deficiencies in an enterprise, was a trait of a prohibited act with all its consequences. Undoubtedly, it is necessary to adjust the Act of Combating Unfair Competition to the provisions of the Directive.

\section{VIII.CONFIDENTIALITY MAINTAINED DURING CIVIL COURT PROCEEDINGS}

According to the analysis of the working document of the European Commission services [Working Document of the Commission Service - Summary of the results assessment Proposal for a Directive of the European Parliament and of the Council on the protection of secret know-how and non-public commercial information (trade secrets) against their unlawful acquisition, use and disclosure, SWD (2013) 472 final, p. 4.8, Brussels, 28 November 2013], the scope of protection of confidentiality of trade secrets during civil proceedings is insufficient, which may lead to a complete loss of a trade secret if the victim decides to refer the case to court. In addition, if trade secret holders were guaranteed confidentiality during court proceedings, they would be more likely to seek legal protection against potential damage resulting from misappropriation of trade secrets. This risk deters victims of misappropriation of trade secrets from pursuing claims. As evidenced by the Baker \& McKenzie 2013 [Working Document of the ....p. 4] study, only three countries in the entire European Union have appropriate regulations that protect the owners of company secrets from disclosure.

In Polish law, the issue of confidentiality during the civil court proceedings is regulated by article 153 . $\S 11$ of the Code of Civil Procedure. This provision is limited only to letting the party ask for a hearing or part thereof in camera. Such a solution, however, does not protect the entrepreneur from disclosing his/her secret to the other party. Much broader and more detailed protection in this area is provided for in the provisions of Directive 2016/943. Above all, the Directive requires (explicitly in article 7 paragraph 2) the Member States to introduce in their legal order such procedures that prevent lodging unfounded applications, in bad faith or in an abusive manner. In addition, the Directive in the wording of article 9 requires the Member States to apply measures and procedures that prevent participants from using or disclosing business secrets that they learned during the process. In contrast to the wording of article 153. $\$ 11$ of the Code of Civil Procedure, the directive gives a real opportunity to keep the subject matter of the proceedings confidential, and also authorizes the court to do so ex officio (Szwaja, 2016). Importantly, the obligation to protect the secret is binding even after the end of legal proceedings. In addition, article 9 paragraph 2 provides for the necessity to introduce in the Polish procedure specific measures necessary for confidentiality. These measures are:

- restrictions on access to all documents containing business secrets or alleged trade secrets submitted by the parties or third parties, in whole or in part, to a limited number of persons;

- restrictions on access to hearings and meetings during which company secrets or alleged trade secrets may be disclosed, as well as minutes or records of such hearings and meetings, to a limited number of persons;

- disseminating every non-confidential version of the court decision to any persons other than persons belonging to a limited number of persons, after removing from this decision any fragments containing the company's secrets.

This provision secures the interests of the holder of the trade secret and offers much better protection of the trade secret by limiting the circle of participants of the proceedings and the prohibition of disclosing confidential information after the end of the process. The content of this provision fills in the gap that currently exists in the Code of Civil Procedure (Zdyb, Sieradzka and Michalak, 2016). In accordance with article 248 of the Penal Code and article 249 on the court order, the defendant is obliged to present documents even if they reveal the secret of the enterprise. It is also not possible to refuse disclosure of confidential information based on article 261 of the Code of Civil Procedure by persons appearing in the trial as witnesses (Ec.europa.eu, 2013), as well as by members of the board citing professional secrecy (Piasecki, 2001).

\section{IX.CONCLUSIONS}

Directive 2016/943 adopted by the European Parliament and the Council of the European Union on 8 June 2016 is undoubtedly an important document that sets the framework for changes in the protection of business secrets in individual EU countries. However, it should be noted that the intention of the EU legislator was to define uniform standards of legal protection, while leaving the Member States a large scope of freedom in the process of transposing the provisions of the Directive into national legal systems.

In Poland it is the Minister of Justice who is responsible for the development of appropriate standards. Preparing amendments of the relevant national rule in order to adjust them to the requirements of the Directive, is a subject of ongoing work. The work started in January 2018 (Legislacja.rcl.gov.pl, n.d.), and currently the consultation stage is under way. The current version of the draft assumes the transposition of the Directive by amending the legal acts that require this amendment. The option of re-writing the whole act regulating the protection of trade secrets has been abandoned. The 
outcomes of public consultations that have been carried out so far indicate a number of objections, which should be taken into account in further work on the implementation of the Directive. The objections concern both substantive and editorial issues of the proposed changes. Most of the proposed changes can be accepted with approval, although there are some which should be omitted. The effect of work on the draft changes can be observed on an ongoing basis on the website of the Government Legislation Centre (Legislacja.rcl.gov.pl, n.d.). Taking into account extremely high validity of the Directive as a tool to counteract unlawful infringements of trade secrets, the transposition of the rules into Polish legal system should be carried out immediately.

\section{X.REFERENCES}

Ec.europa.eu. (2013). [online] Available at: http://ec.europa.eu/internal_market/iprenforcement/docs/tradesecrets/130711_final-study_en.pdf.

Gancarz, I. (2011). Pojęcie przedsiębiorstwa w świetle relacji pomiędzy unijnym i krajowym prawem konkurencji. Kwartalnik Prawa Publicznego, 11(3/4), p.96

Gawlik, B. (1985). Ochrona dóbr osobistych. Sens i nonsens tzw. praw podmiotowych osobistych. Scientific Journals of the Jagiellonian University. Prace z Wynalazczości i Ochrony Własności Intelektualnej, 41, p.138.

Giesen, B. (2013). Ochrona tajemnicy przedsiębiorstwa na gruncie art.11 u.z.n.k. Studia prawa prywatnego, 29(2), pp.17-18.

Gnela, B. (2015). o specyfice autorskich dóbr osobistych oraz koncepcji ich ochrony. Ruch Prawniczy, Ekonomiczny i Socjologiczny, LXXVII(2), p.35.

Gniewek, E. (2010). Kodeks cywilny. Komentarz. Warszawa, p.126.

Legislacja.rcl.gov.pl. (n.d.). Projekt. [online] Available at: http://legislacja.rcl.gov.pl/projekt/12306806/katalog/12482406\#12482406.

Michalak, A. (2006). Ochrona tajemnicy przedsiębiorstwa, Zagadnienia cywilnoprawne. Zakamycze, p.45 and n.

Miemiec, M. (2013). Materialne prawo administracyjne. Warszawa: Wolters Kluwer Polska, SA., p.311.

Partyk, A. (2015). [online] Available at: http://www.lex.pl/czytaj/-/artykul/worzecznictwie-trwa-spor-czy-osoba-prawna-ma-prawo-do-ochrony-swojegowizerunku [Accessed 9 Nov. 2015].

Pazdan, M. (2007). System prawa prywatnego. In: M. Safjan, ed., Prawo cywilne - część ogólna. Warszawa, p.1149.

Piasecki, K. (2001). Kodeks postępowania cywilnego. Komentarz, Tom I. Warszawa: CH Beck.

Romatowska, M. (n.d.). Temidium. [online] Temidium.pl. Available at: https://www.temidium.pl/artykul/zadoscuczynienie_za_krzywde_na_gruncie_ kodeksu_cywilnego_aspekty_praktyczne-287.html.

Szwaja, J. (2016). Ustawa o zwalczaniu nieuczciwej konkurencji”. Komentarz. 4th ed. Warszawa: $\mathrm{Nb} 67$.

Wojcieszko-Głuszko, E. (2005). Tajemnica przedsiębiorstwa i jej cywilnoprawna ochrona na podstawie przepisów prawa nieuczciwej konkurencji. ZN UJ PIPWI, 89, pp.9-138.

Zdyb, M., Sieradzka, M. and Michalak, A. (2016). Komentarz do 'Ustawa o zwalczaniu nieuczciwej konkurencji’. Warszawa, p. 400, 409, 417, 4 